\title{
FLAVONOIDS OF THE LEAVES
}

\section{OF Andromeda polifolia}

V. L. Shelyuto, V. I. Glyzin,

and V. P. Sinyak

In a study of the chemical composition of the leaves of Andromeda polifolia (bogrosemary andromeda), family Ericaceae, collected in June, 1972, in the environs of Vitebsk by two-dimensional chromatography on paper in the butan-1-ol-acetic acid-water $(4: 1: 5)$ and $15 \%$ acetic acid systems, we found four substances of flavonoid nature.

On separating an ethanolic extract on Kapron using ethanol-chloroform as eluent, two flavonoid substances were obtained.

Substance I with the composition $\mathrm{C}_{15} \mathrm{H}_{10} \mathrm{O}_{7}, \mathrm{mp} 309-311^{\circ} \mathrm{C}$ (mp of the acetate $\left.197-199^{\circ} \mathrm{C}\right), \lambda_{\max }(\mathrm{meth}-$ anol) $256,375 \mathrm{~nm}$.

Substance II, composition $\mathrm{C}_{20} \mathrm{H}_{18} \mathrm{O}_{11} \cdot{ }^{1} /{ }_{2} \mathrm{H}_{2} \mathrm{O}, \mathrm{mp} 239-241^{\circ} \mathrm{C},[\alpha]_{D}-96.4^{\circ}$ (c 3.11; formamide), $[\alpha]_{D}$ $-53.1^{\circ}$ (c 1.41; methanol); $\lambda$ max $258,373,362 \mathrm{~nm}$.

On the basis of hydrolysis products, UV spectroscopy with ionizing and complex-forming additives, and IR and NMR spectroscopy, substance (I) was identified as quercetin and substance (II) was guaijaverin.

Vitebsk Medical Institute. Translated from Khimiya Prirodnykh Soedinenii, No. 4, p. 555, July-August, 1973. Original article submitted January 30,1973.

(C) 1975 Plenum Publishing Corporation, 227 West 17th Street, New York, N.Y. 10011. No part of this publication may be reproduced, stored in a retrieval system, or transmitted, in any form or by any means, electronic, mechanical, photocopying, microfilming, recording or otherwise, without written permission of the publisher. A copy of this article is available from the publisher for $\$ 15.00$. 